\section{Fahrurrozi $^{1}$ \\ Murtono \\ Ika Lestari \\ Iva Sarifah \\ Ratna Sari Dewi}

Article info:

Received 14.06.2020

Accepted 26.10.2020

UDC - 005.336.3:37.018.43 DOI - 10.24874/IJQR15.01-06

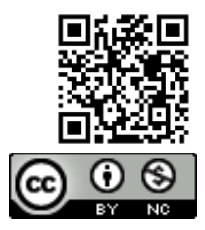

\title{
THE USEFULNESS OF ONLINE LEARNING ON QUALITY OF EDUCATION DURING COVID-19 PANDEMIC: EVIDENCE FROM THE DEPARTMENT OF ELEMENTARY SCHOOL TEACHER EDUCATION AT UNIVERSITAS NEGERI JAKARTA, INDONESIA
}

Abstract: The objective of the study is to examine the
usefulness of online learning for improving quality of
instruction, quality of environment, quality of teacher and
quality of family cooperation during the COVID-19 pandemic
in Indonesia. The study collected 296 sample responses from
the Department of Elementary School Teacher Education at
Universitas Negeri Jakarta via purposive sampling through
self-administrated survey questionnaire. The results showed
that the usefulness of online learning significantly influenced
the quality of environment. Usefulness of online learning
significantly influenced the quality offamily cooperation. Also,
the usefulness of online learning significantly influenced the
quality of instruction. Lastly, the usefulness of online learning
significantly influenced the quality of teachers. Students are
required not only to respond to the questions of the instructor
but also to give feedback regarding the online class in the
pandemic to perform better in discussions, activities, and tasks.

Keywords: Quality of Education; Online Learning Usefulness; COVID-19 Pandemic; Indonesia.

\section{Introduction}

The rapid increase in the usage of internet and online learning has taken its place very well and proved to be one of the growing platforms in the area of education by using several technologies (B. Bates, 2019; Cigdem \& Yildirim, 2014; Roy et al., 2020). However, when education is done through the internet, it is not only the institutions that want to teach students that are using this option; rather, there has also been an increase in the number of people who want different types of certifications by utilizing the internet through online classes and online courses. Many

1 Corresponding author: Fahrurrozi

Email: fahrurrozi@unj.ac.id students have the objective to gain more knowledge that can be achieved through online learning or by working on critical determinants that affect individual satisfaction through the online environment (Bolliger \& Halupa, 2018; Dziuban et al., 2015; Liaw \& Huang, 2013; Shelton, Hung, \& Lowenthal, 2017; Weidlich \& Bastiaens, 2018; Yang, Baldwin, \& Snelson, 2017). According to the past studies, Horzum, Kaymak, and Gungoren (2015); Kuo (2014) it has been determined that the determinants must be effective for the individual performance who are learning through the internet, whereas a small portion of research has been done to see the relationship among 
few factors. For example, the students' general views or ideas on online learning, online learning performance, readiness or even course satisfaction. Researchers used to evaluate the students' performance, but the impact of COVID-19 pandemic has shaken the world (Walker et al., 2020) and all sectors and industries are badly affected (Bernard, Brauer, Abrami, \& Surkes, 2004; Hao, 2016; Lu, Yu, \& Liu, 2003). The education system in Indonesia is no different and is also significantly impacted by the COVID-19 pandemic.

Furthermore, the researcher has highlighted the online courses where many different learning activities can be seen in the discussion on a specific topic during this global pandemic of COVID-19 where individuals or groups are required to post their tasks or assignments and even attend exams in the digital classroom (Viner et al., 2020). In addition to that, a few papers further defined the students regarding the learning performance that can be taken as a combination of various scores. For instance, the actual number of students who are posting in online discussion boards along with the examination scores and as well as assignment scores (Picciano, 2002; Huei-Chuan Wei \& Chou, 2019; Huei-Chuan Wei, Peng, \& Chou, 2015). Furthermore, the online courses in the present following COVID-19 consists of course orientations, two papers, and pencil examination along with the individual or group projects and weekly online discussions apart from the class (Setiawan, 2020).

According to Cheng and Cheung (2004) the quality in general has significant importance and it has been considered as the sum of the factors that directly influence the goods and services that further depend on the level of satisfaction along with the needs of the students. The initial researchers were the ones who used to define the excellent quality factor in education. However, the education quality is one of that includes how individual learning must be organised, how it can be managed or taught, and the level of training along with the outcomes that must be achieved during the times of pandemic (Akyüz, 2014; Erberber, 2010; Mullis, Martin, Foy, \& Arora, 2012; OECD, 2013; Sezer, Güner, \&Ispir, 2012). Crawford, Butler-Henderson, Rudolph, and Glowatz (2020) mentioned that quality in education has developed the schools in a very effective way where various types of studies can be done easily and COVID-19 could also be effective in providing proper infrastructure for online education. Lezotte (1991) explained that the school is an effective place where the mission is clear to educate the students with a good quality of content and the priorities, standard, process and accountability that are clear which would help tremendously during COVID-19 (Crawford et al., 2020). Moreover, according to Fisher and Cresswell (1998); Townsend (1997), the school is known as effective when there will be effective leadership along with the human resource management (HRM) along with a supportive environment for those who are learning with their parents. Furthermore, Gamage (2001) highlighted the high level of expectation that has to exist in ineffective schools' growth that is more visible and accessible along with fair stakeholders.

However, in an efficient school system, along with the quality of education during the COVID-19 pandemic, the literature must be effective and the focus must be on concepts from education management (Ting, Carin, Dzau, \& Wong, 2020). The mentioned properties have an important role in the circulation of properties. However, studies explain that in schools, parents always question what good teaching and effective teaching are about. This is the part of educational research that has a long and well elaborated answer (Richardson \& Thomas, 1989; Ubuz\&Sar1, 2009). A review done by conducting some studies that highlighted that there are no special definitions on the online teaching situation in times of pandemic. It differs in the context of the course. For instance, a qualified mathematics teacher must have the desired qualities to give importance to the factors that vary from the 
stakeholders in the research of students. This involved the teacher's position that is purely based on their education level in terms of teaching skills or experience and how they can be fully utilised during COVID-19 (Setiati \& Azwar, 2020). Furthermore, the author has identified good quality teachers that are content knowledgeable, followed by another which is honesty and the general knowledge in every regard (Buaraphan, 2012). In the teaching field there are a lot of issues regarding knowledge, pedagogical knowledge, and more, whereas content knowledge during the COVID-19 pandemic has become a real issue in this field (Pragholapati, 2020).

Moreover, one of the main things in academic, social and psychological development is when the students want to feel the comfort zone along with a happy and safe environment where they can build up their mind and personality in a positive way. Along with this statement, schools have been considered as the primary ground that is responsible for the multifaceted education that is mainly close to the other variables. For example, all kinds of students' achievements can be done among studies that further continue the student perspective that leads this course to further their view and curiosity for these courses to reflect their level of achievement. However, due to the COVID-19 pandemic, this situation cannot be applied for schools and the students (Pragholapati, 2020). Furthermore, Glasser (1999) states that the students who are of a new era have expectations from the school. They are not only thinking about the academic level or achievement but rather want quality school life experiences such as social, sporting, cultural, transportation along with technical that further positively contributes to the individual lives. All of these are affected by the pandemic. In addition to this, the exams are the grounds which further evaluates the students' performance. This allows students and teachers to keep it in a simple way when they study after the given exam time in order for them to up be promoted to the next class.
After the exam, parents ask the teachers the specific reasons if the child failed or succeed. To see the performance of the teachers, the principals are required to see and evaluate them to become more effective teachers. Hence the positive relationship further builds the variable between named examinations and students' performance to check the education system (Brian, 2007; Wößmann, 2003).

Covid-19 has turned out to be one of the biggest disasters of modern time. The whole world has been suffering. Indonesia is no exception and as of 13th June 2020, there are over 37,000 recorded cases in Indonesia (WHO, 2020; Worldometer, 2020). The education systems around the world are also affected with over 530,000 schools closed and more than 68 million students affected and shifting towards online education. However, unlike the developed countries, the Indonesian education system does not seem to possess the infrastructure to scale up to the online education as privacy and security risks also exist online in Indonesia.

\section{Literature Review}

Learning in the online platform can be easily done through computers and the internet. The author concluded from the research that the student's perception towards computer learning life has been considered as important for their future to learn that type of technology (Alzahran i\& O'Toole, 2017; Joyce \& Kirakowski, 2015; Huei-Chuan Wei \& Chou, 2019). In addition to this, students' attitude towards web and web-based guidelines can easily affect their future where the material has been provided along with instructions that are usually provided on the web. Influence takes place when the lesson takes place and students themselves start learning through an online environment. Furthermore, research has been done in different platforms where the students developed an online learning experience and have always noticed the one issue that learners view in the ground of online learning 
(Al-Samarraie, Teng, Alzahrani, \& Alalwan, 2018; P.-C. Sun, Tsai, Finger, Chen, \& Yeh, 2008). The author further highlights the example that college students have on the view regarding online learning environment that have four boundaries where e-learning itself is a self-learning environment, elearning has been taken as the effective learning environment, e-learning always uses as multi-media instruction environment, and e-learning has been considered as instructorbased learning environment (Liaw, Huang, \& Chen, 2007). Likewise, the authors have not focused on the features of online learning like flexibility, adaptability, and the interaction between parties but have a checklist on the factors of online learning that were applied on the self-determination theory as a theoretical framework (Deci \& Ryan, 1985). Huei-Chuan Wei and Chou (2019) also states that it can be understood by the students as a personal motivational determinant for online learning. The 21statement which has been studied and further categorised into the five sub-dimensions to fit in the SDT framework Furthermore, the two sub-dimensions were learning needs and personal learning preferences that were grouped into the factors of perceived competence. Another two sub-dimensions are personal learning enjoyment and flexibility that was further grouped into the dimension of perceived autonomy. The last subdimension is the interaction that has to be fit in the factors of perceived relatedness ground from the platform of SDT framework. According to the statement above, there are several determinants that can be highlighted by the learners in online learning. For instance, online learning provides learners a more flexible and convenient learning environment that conducts self-paced and customised learning. In addition to this, the platform of online learning can be improved by the interaction between the students, instructors, and groups through these communication technologies. Therefore, the online learning perception helps to study the learners' recognition of the benefits of online learning. It can be said that the learners are motivated to use the online learning platform and show positive attitudes towards it. However, the desired aspects of online learning were identified from the online reviews. Therefore, this research is attempting to develop a comprehensive framework on the online learning perception and the suitable instruments that will help the learners to measure their perception on online learning. Furthermore, De Paepe, Zhu, and Depryck (2018); Ke and Kwak (2013) investigated the key components that affected the student performance on online learning. For instance, A. T. Bates (2018); Morris (2010) highlighted the area of college students' views and their experiences with the internet had been critically affecting their performance that was conducted through online learning. The authors further explored the relationship among the college students' perceptions the user of the internet for educational purposes and their behavior as stated by Duggan, Hess, Morgan, Kim, and Wilson (2001). Furthermore, the outcomes indicated a positive attitude towards online learning that will cause higher tendency of selection on online class by the students.

Moreover, the data collected from the students total to a number of 2,196 in Australia and were extracted from the universities. The findings suggested that students appreciate online learning for their interest because it supports self-regulated learning. However, another outcome highlighted that the online components for all the platforms applied on the calculations and the transfer of one's knowledge to another. Likewise, the authors investigated the relationship between the learners' online learning insight and the learning achievement from the courses.

Furthermore, online learning activities take place when the students are having learning sessions and face-to-face learning activities which are important and require them to be active during the class. However, However, Sun, Xie, and Anderman (2018) argue on the research on FC that have existed long in the 
education sector which require students to attend the class and learn through the internet and the computer.

The concept of online learning was given by Warner, Christie, and Choy (1998) and became important due to the pandemic situation. To understand the concept of readiness, the researchers introduced a tool to examine the readiness for online learning. McVay (2000) introduced a 13-item instrument to examine the readiness of students to learn. Toevaluate the questionnaire, Smith, Murphy, and Mahoney (2003) claimed that the online learning readiness can include two major elements which are the comfort of students with the available resources of learning in a sequence and the level of self-dedication. Bernard et al. (2004) formed a questionnaire with 38 items to find out the four readiness dimensions: distance education belief, confidence in the skills, initiative and self-direction, and the interaction desire with other students and teachers.

However, to measure the online learning readiness, the other factors like technical efficacy of the computer usage, the efficacy of self-control, and the navigation skills of the internet have to be considered. Dray, Lowenthal, Miszkiewicz, Ruiz-Primo, and Marczynski (2011) introduced a model for self-evaluation on the readiness of students for online learning. This model studied four different dimensions: basic technical skills like the usage ability for different applications in different ways (the internet, email, documents, and spreadsheet), the measurement of the technology, the involvement of the connectivity of the internet, the usage of technology on the frequency and nature of usage, and the connection with the communication and information technology. $\mathrm{Yu}$ and Richardson (2015) looked into the social integration and considered it as a significant factor for readiness in online learning and they proposed further on the conceptual model of online learning readiness with four different elements: classmates' social competencies, instructor related social competencies, competencies with communication, and the competencies related to technology.

The online learning environments have flexible structures that allow students to be involved and be self-regulated in their process of learning. In such condition, the abilities and willingness to manage their resources, time, and the available strategies to attain goals are very important for the learning outcomes of the students (Newman, Deyoe, Connor, \& Lamendola, 2014). Broadbent and Poon (2015) conducted a review of 12 different studies on the effect of SRL on the academic achievements of studies in the higher education in online settings and the results indicated that time management, regulation of effort, meta-cognition and critical thinking have a positive relationship with the learning outcomes of the students.

To further develop the factors to study the readiness of students, some academicians have studied the factors that have an impact on the results of online learning. Hung, Chou, Chen, and Own (2010) formed a multidimensional model to analyse the readiness of college students for their online learning based on five different dimensions: learning motivation, self-direction of learning, self-efficacy of the internet, learner control, and the self-efficacy on online communication. The results of the analysis showed that the readiness levels of online studies were at a higher side in the selfefficacy of the internet or computer, learning motivation, and self-efficacy of communication, but it was at a lower side in the self-directed learning and the learner control. Hung (2012) also studied the association between the readiness of online learners and the performance of learning. It was discovered that the readiness of students were not in the position to explain the performance of learning. Keramati, AfshariMofrad, and Kamrani (2011) developed a model to study the effects of readiness in the association between the factors and results of online learning. The analysis revealed that the factors of readiness have a moderate effect 
between the factors of online learning and the results of this learning. Furthermore, the factors of organisational readiness bring a significant impact on students' results. Adding to this, the readiness of online learning was found to be a significant element for the students' learning performance in a course conducted online. Researchers further examined and discovered that the association between the learning perceptions of students while online and their readiness for online learning are limited. Furthermore, the studies have shown that the online learning readiness is a multifaceted idea as stated by Hung (2016); Hung et al. (2010); Keramati et al. (2011); McVay (2000) involved the instruments like skill efficacy of the computer usage, efficacy of self-control, and the selfefficacy for online communication.

Chow and Shi (2014) identified that the perceptions of university students for elearning including the perceived motivation and flexibility, have significant effects on elearning satisfaction. Furthermore, Paechter, Maier, and Macher (2010) established that the online interaction between the instructor and the student is a significant element that affects the satisfaction of students in the online learning environments. In the same way, McFarland and Hamilton (2005) confirmed that the majority of the students are satisfied with the feature of the discussion board in the online learning environment. It can be said that the students consider the discussion in online sessions as the most important activity in learning in the online classes. This concept was also found true by Lee, Srinivasan, Trail, Lewis, and Lopez (2011) which confirmed the perceptions of students on peer interactions and the significant relationship with the teachers in the online course satisfaction of the students. The consistency in these studies shows that the perceptions of students on online learning can affect their satisfaction level of the online course.

Furthermore, Stokes (2003) identified that the satisfaction from online courses by the students was affected by the level of comfort in using the internet. Sahin and Shelley
(2008) showed that the students which had great satisfaction with their online classes are those who are skilled to utilise online tools and these students considered online learning as an important way of communicating, sharing, and learning. Then, Kuo, Walker, Belland, and Schroder (2013) also identified that the self-efficacy from using the internet predicts the satisfaction of students for their online learning. A study by Kuo et al. (2013) mentioned that self-learning contributed nothing to the satisfaction of students in their courses. It can be said that this result is contradictory to the past studies that showed self-regulation which plays an important role to bring student satisfaction.

In the past, different SRL related frameworks and models were developed by researchers to show the regulation process of the students for their performance and learning to be sensible and responsible when learning in the environment of online learning. This study defined SRL operationally and conceptually through different factors that were introduced by Barnard, Lan, To, Paton, and Lai (2009) to study SRL in the environment of online learning. These factors are goal setting, environmental structuring, time management, self-evaluation, and task strategies.

However, the past studies that are mentioned above urged to explore new perceptions of online learning and the factors that improve the performance and the insight of the learner. As for hypothesis of this study is Usefulness of online learning during COVID-19 has significant effect (1) quality of instruction, (2) quality of environment, (3) quality of teacher, and (4) quality of family cooperation.

\section{Research Methods}

\subsection{Study Design}

There are various philosophies to choose from for a researcher to carry out a study. One of the commonly used philosophies is the positivistic philosophy. The positivism philosophy adheres to the idea that 
knowledge is mainly obtained through facts with the help of observing, sensing, or measuring can be trusted (Kajornboon, 2005). The researchers play a limited part in the collection of data and its interpretations. Positivism is a type of research where results are commonly quantifiable and observable (Hyde, 2000). The positivistic philosophy was used as the study was knowledge-based. The quantitative research is a choice of research where the researcher collects data that are present in numbers and can be analysed with the help of statistical techniques (Marczyk, DeMatteo, \& Festinger, 2005). The data is collected from a population that is assumed to provide the relevant data. The numerical data is used for data analysis and the outcomes are more applicable to the target population (Scott \& Garner, 2013). The quantitative choice was adopted as the research aimed to test the hypotheses using the numerical data.

The cross-sectional time horizon is where the data is collected by the researcher at one point at a time instead of collecting it from the same population over different points of time (Goddard \& Villanova, 2006). The data is collected from people of different demographics however, they match the profile of the target population and can provide the relevant data (Gomm, 2008). The cross-sectional time horizon was used in the study as the data is collected from a single point of time from people of various demographics.

\subsection{Sampling Design}

There are two main types of sampling techniques that can be used by the researchers which are the probability sampling technique and the non-probability sampling technique. The non-probability sampling is where the data is collected from the population in a way that no one in the sample has equal chances of representation (Cochran, 2007). There are different types of non-probability sampling techniques and one of which is the purposive sampling technique. The purposive sampling technique is where the data is collected from the experts from the industries due to their expertise in the field and the richness of data (Krejcie\& Morgan, 1970). The purposive sampling was used as the data was supposed to be collected from people that can provide data that is abundant in the information.

The data was collected using the survey questionnaire method. For the questionnaire, the five-point Likert scale was adopted. Interviews were conducted from the target population and face to face close-ended questions were incorporated in the study. The study collected 296 samples from the Department of Elementary School Teacher Education at Universitas Negeri Jakarta, Indonesia.

\subsection{Data Analysis}

For the analysis of data, various data analysis techniques were used by the researchers. The PLS-SEM which stands for "Partial Least Squares Structural Equation Modeling" technique, is a type of data analysis technique that allows the researcher to examine the complex association between the variables and the cause and effect of relationship among them (Nitzl, 2018). The PLS-SEM was used as it allows the association among the variables with great accuracy.

\section{Data Analysis}

\subsection{Demographic Profile}

Table 1 represents the demographic profile of participants. The table shows that there were a total of 296 respondents. Among the respondents, $104(35.1 \%)$ were males and 192 $(64.9 \%)$ were females. In age, $129(43.6 \%)$ were 19 to 21 years old, $167(56.4 \%)$ were 22 to 24 years old. All of them were undergraduates where $147 \quad(49.7 \%)$ had previous experience in online courses and 149 $(50.3 \%)$ were enrolling in online courses for the first time. 
Table 1. Demographic Profile $(n=296)$

\begin{tabular}{|c|c|c|c|}
\hline & & Frequency & Percent \\
\hline \multirow{2}{*}{ Gender } & Male & 104 & 35.1 \\
\cline { 2 - 4 } & Female & 192 & 64.9 \\
\hline \multirow{2}{*}{$\begin{array}{c}\text { Age Group (age range } \\
19-24 \text { years) }\end{array}$} & 19 Years to 21 Years & 129 & 43.6 \\
\cline { 2 - 4 } Current Enrollment & 22 Years to 24 Years & 167 & 56.4 \\
\cline { 2 - 4 } & Undergraduates & 296 & 100.0 \\
\hline Experience & Previous Experience with Online Courses & 147 & 49.7 \\
\hline
\end{tabular}

\subsection{Measurement Model}

The figure 1 is the measurement model used

The table 2 represents the measurement in this study.

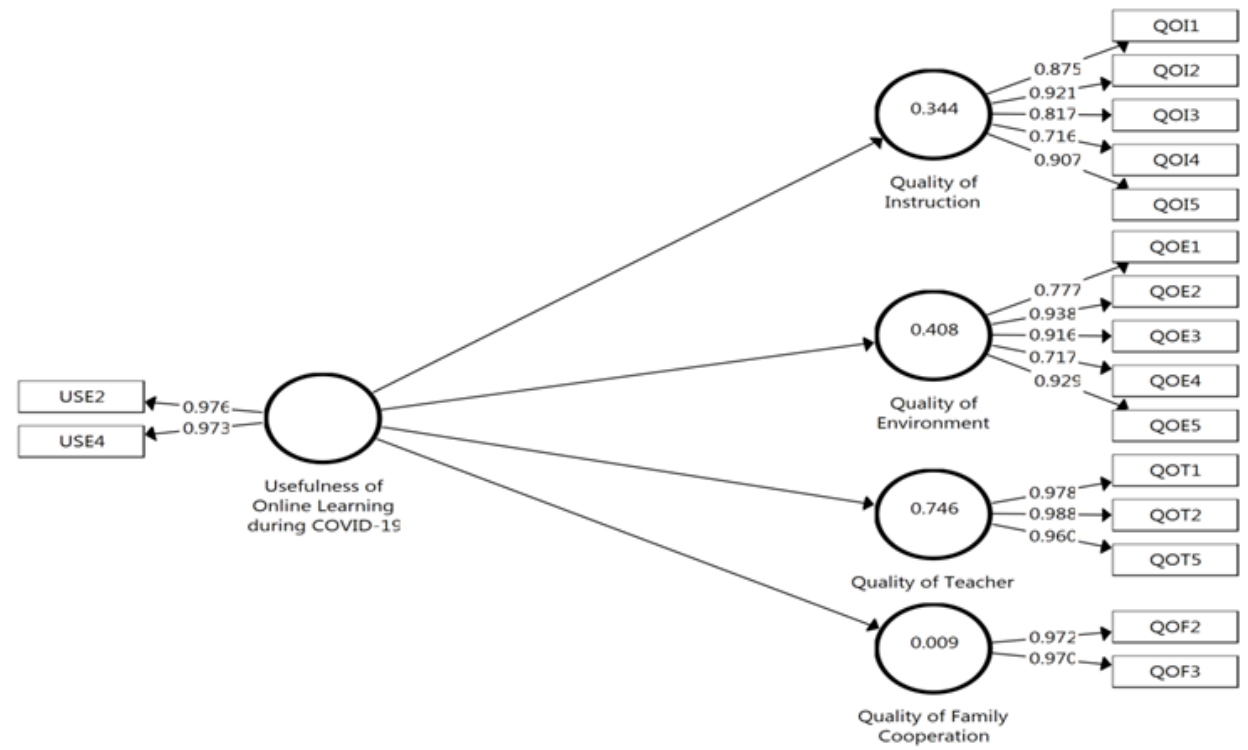

Figure 1. PLS Algorithm using SmartPLS version 3.2.8

Table 2. Measurement Model

\begin{tabular}{|c|c|c|c|c|}
\hline Variables & Items & Loading & Composite Reliability & $\begin{array}{l}\text { Average Variance Extracted } \\
\text { (AVE) }\end{array}$ \\
\hline \multirow{5}{*}{ Quality of Environment } & QOE1 & 0.777 & \multirow{5}{*}{0.934} & \multirow{5}{*}{0.740} \\
\hline & QOE2 & 0.938 & & \\
\hline & QOE3 & 0.916 & & \\
\hline & QOE4 & 0.717 & & \\
\hline & QOE5 & 0.929 & & \\
\hline \multirow{2}{*}{ Quality of Family Cooperation } & QOF2 & 0.972 & \multirow{2}{*}{0.970} & \multirow{2}{*}{0.942} \\
\hline & QOF3 & 0.970 & & \\
\hline \multirow{5}{*}{ Quality of Instruction } & QOI1 & 0.875 & \multirow{5}{*}{0.929} & \multirow{5}{*}{0.724} \\
\hline & QOI2 & 0.921 & & \\
\hline & QOI3 & 0.817 & & \\
\hline & QOI4 & 0.716 & & \\
\hline & QOI5 & 0.907 & & \\
\hline
\end{tabular}


Table 2. Measurement Model (continued)

\begin{tabular}{|c|c|c|c|c|}
\hline Variables & Items & Loading & Composite Reliability & $\begin{array}{l}\text { Average Variance Extracted } \\
\text { (AVE) }\end{array}$ \\
\hline \multirow{3}{*}{ Quality of Teacher } & QOT1 & 0.978 & \multirow{3}{*}{0.983} & \multirow{3}{*}{0.951} \\
\hline & QOT2 & 0.988 & & \\
\hline & QOT5 & 0.960 & & \\
\hline \multirow{2}{*}{$\begin{array}{c}\text { Usefulness of Online Learning } \\
\text { during COVID-19 }\end{array}$} & USE2 & 0.976 & \multirow{2}{*}{0.974} & \multirow{2}{*}{0.950} \\
\hline & USE4 & 0.973 & & \\
\hline
\end{tabular}

The table shows that the values of outer loadings of all constructs were greater than 0.70 . It is recommended that the values over 0.70 should be retained with values lower than 0.40 should be removed and values over 0.40 and smaller than 0.70 can be retained for convergent validity (Sarstedt, Ringle, Smith, Reams, \& Hair, 2014). Moreover, the values of CR and AVE should be over 0.70 and 0.50 (Hair, Ringle, \& Sarstedt, 2011). All the constructs had CR and AVE over 0.70 and 0.50 , hence, construct validity was achieved.

\subsection{Discriminant Validity}

\section{Fornell\&Larcker Criterion}

The table 3 represents Fornell \& Larcker. The table shows that the diagonal bold values were greater than the values presented in vertical settings (Fornell \& Larcker, 1981), hence the discriminant validity was achieved using Fornell\&Larcker criterion.

Table 3. Fornell-Larcker Criterion

\begin{tabular}{|l|l|l|l|l|l|}
\hline & QOE & QOF & QOI & QOT & USE \\
\hline $\begin{array}{l}\text { Quality of } \\
\text { Environment }\end{array}$ & $\mathbf{0 . 8 6 0}$ & & & & \\
\hline $\begin{array}{l}\text { Quality of } \\
\text { Family } \\
\text { Cooperation }\end{array}$ & 0.314 & $\mathbf{0 . 9 7 1}$ & & & \\
\hline $\begin{array}{l}\text { Quality of } \\
\text { Instruction }\end{array}$ & 0.475 & 0.663 & $\mathbf{0 . 8 5 1}$ & & \\
\hline $\begin{array}{l}\text { Quality of } \\
\text { Teacher }\end{array}$ & 0.771 & 0.326 & 0.532 & $\mathbf{0 . 9 7 5}$ & \\
\hline $\begin{array}{l}\text { Usefulness } \\
\text { of Online } \\
\text { Learning } \\
\text { during } \\
\text { COVID-19 }\end{array}$ & 0.639 & 0.092 & 0.586 & 0.864 & $\mathbf{0 . 9 7 5}$ \\
\hline
\end{tabular}

\section{Cross Loadings}

The table 4 represents the cross loadings for discriminant validity.

Table 4. Cross Loadings

\begin{tabular}{|c|c|c|c|c|c|}
\hline & QOE & QOF & QOI & QOT & USE \\
\hline QOE1 & $\mathbf{0 . 7 7 7}$ & 0.011 & 0.344 & 0.418 & 0.434 \\
\hline QOE2 & $\mathbf{0 . 9 3 8}$ & 0.339 & 0.474 & 0.733 & 0.556 \\
\hline QOE3 & $\mathbf{0 . 9 1 6}$ & 0.381 & 0.363 & 0.728 & 0.505 \\
\hline QOE4 & $\mathbf{0 . 7 1 7}$ & 0.176 & 0.219 & 0.408 & 0.335 \\
\hline QOE5 & $\mathbf{0 . 9 2 9}$ & 0.351 & 0.536 & 0.862 & 0.767 \\
\hline QOF2 & 0.324 & $\mathbf{0 . 9 7 2}$ & 0.641 & 0.321 & 0.091 \\
\hline QOF3 & 0.285 & $\mathbf{0 . 9 7 0}$ & 0.645 & 0.313 & 0.088 \\
\hline QOI1 & 0.333 & 0.512 & $\mathbf{0 . 8 7 5}$ & 0.324 & 0.495 \\
\hline QOI2 & 0.345 & 0.558 & $\mathbf{0 . 9 2 1}$ & 0.310 & 0.465 \\
\hline QOI3 & 0.405 & 0.611 & $\mathbf{0 . 8 1 7}$ & 0.420 & 0.398 \\
\hline QOI4 & 0.443 & 0.514 & $\mathbf{0 . 7 1 6}$ & 0.620 & 0.562 \\
\hline QOI5 & 0.468 & 0.616 & $\mathbf{0 . 9 0 7}$ & 0.530 & 0.525 \\
\hline QOT1 & 0.789 & 0.323 & 0.528 & $\mathbf{0 . 9 7 8}$ & 0.845 \\
\hline QOT2 & 0.796 & 0.300 & 0.529 & $\mathbf{0 . 9 8 8}$ & 0.890 \\
\hline QOT5 & 0.666 & 0.335 & 0.498 & $\mathbf{0 . 9 6 0}$ & 0.788 \\
\hline USE2 & 0.623 & 0.144 & 0.546 & 0.907 & $\mathbf{0 . 9 7 6}$ \\
\hline USE4 & 0.623 & 0.032 & 0.599 & 0.772 & $\mathbf{0 . 9 7 3}$ \\
\hline
\end{tabular}

The table illustrates that the cross-loading values were higher in their constructs compared to the loadings in other constructs (Hair, Black, Babin, \& Anderson, 2010). Therefore, discriminant validity using crossloading has been achieved.

\section{HTMT}

The table 5 represents the HeterotraitMonotrait (HTMT) ratio for discriminant validity. The table shows that the values in the table were below the cutoff threshold value of 0.90 as recommended (Henseler et al., 2014), hence discriminant validity using HTMT is achieved. 
Table 5. Heterotrait-Monotrait Ratio

\begin{tabular}{|l|c|c|c|c|c|}
\hline & QOE & QOF & QOI & QOT & USE \\
\hline Quality of Environment & 0.318 & & & & \\
\hline $\begin{array}{l}\text { Quality of Family } \\
\text { Cooperation }\end{array}$ & 0.492 & 0.720 & & & \\
\hline Quality of Instruction & 0.775 & 0.342 & 0.554 & & \\
\hline Quality of Teacher & 0.651 & 0.096 & 0.625 & 0.895 & \\
\hline $\begin{array}{l}\text { Usefulness of Online } \\
\text { Learning during COVID-19 }\end{array}$ & & & & \\
\hline
\end{tabular}

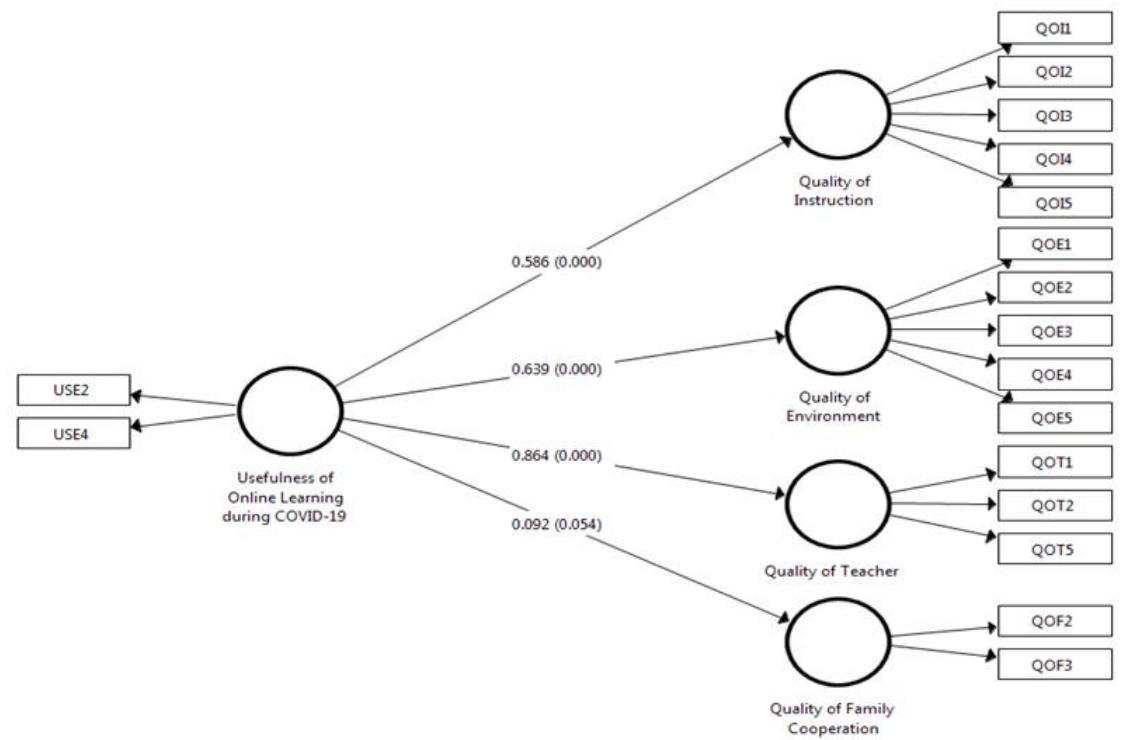

Figure 2. PLS Bootstrapping using SmartPLS version 3.2.8

\section{Path Analysis}

The table 6 represents the path analysis. The table shows that the usefulness of online learning during COVID-19 was significantly influencing the quality of environment (0.639, $\mathrm{P}<0.10)$. The usefulness of online learning during COVID-19 was significantly influencing the quality of family cooperation (0.092, $\mathrm{P}<0.10)$. Also, the usefulness of online learning during COVID-19 was significantly influencing the quality of instruction $(0.586, \mathrm{P}<0.10)$. Lastly, the usefulness of online learning during COVID19 was significantly influencing the quality of teacher $(0.864, \mathrm{P}<0.10)$.

Table 6. Path Coefficients

\begin{tabular}{|c|c|c|c|c|}
\hline & Estimate & Std. Dev. & T-Stats & Prob. \\
\hline $\begin{array}{c}\text { Usefulness of Online Learning during } \\
\text { COVID-19 } \rightarrow \text { Quality of Environment }\end{array}$ & 0.639 & 0.039 & 16.530 & 0.000 \\
\hline $\begin{array}{c}\text { Usefulness of Online Learning during } \\
\text { COVID-19 } \rightarrow \text { Quality of Family Cooperation }\end{array}$ & 0.092 & 0.057 & 1.607 & 0.054 \\
\hline $\begin{array}{c}\text { Usefulness of Online Learning during } \\
\text { COVID-19 } \rightarrow \text { Quality of Instruction }\end{array}$ & 0.586 & 0.031 & 19.122 & 0.000 \\
\hline $\begin{array}{c}\text { Usefulness of Online Learning during } \\
\text { COVID-19 } \rightarrow \text { Quality of Teacher }\end{array}$ & 0.864 & 0.016 & 53.675 & 0.000 \\
\hline
\end{tabular}




\section{Predictive Relevance}

The table 7 represents the predictive relevance.

Table 7. Predictive Relevance

\begin{tabular}{|l|c|c|c|}
\hline & R Square & $\begin{array}{c}\text { R Square } \\
\text { Adjusted }\end{array}$ & Q Square \\
\hline $\begin{array}{l}\text { Quality of } \\
\text { Environment }\end{array}$ & 0.408 & 0.406 & 0.267 \\
\hline $\begin{array}{l}\text { Quality of } \\
\text { Family } \\
\text { Cooperation }\end{array}$ & 0.009 & 0.005 & 0.008 \\
$\begin{array}{l}\text { Quality of } \\
\text { Instruction }\end{array}$ & 0.344 & 0.342 & 0.224 \\
\hline $\begin{array}{l}\text { Quality of } \\
\text { Teacher }\end{array}$ & 0.746 & 0.745 & 0.669 \\
\hline
\end{tabular}

The table showed that the independent constructs were explaining the quality of environment $40.8 \%$, quality of family cooperation $0.9 \%$, quality of instruction $34.4 \%$, and quality of teacher $74.6 \%$ as denoted by the R-square values. Lastly, the values of $\mathrm{Q}$-square were also above absolute zero.

\section{Conclusion and Recommendations}

In the present study, the online learning perception that influenced the online learning readiness and its effects is highlighted during the COVID-19. Another observation noticed is that when students were motivated in learning through the internet. The findings of the current study showed the results of the past studies which categorised the effects the online readiness factors.

The authors proposed that online learning readiness is influenced by comfort zone and must be provided by the school or college management (Smith et al., 2003). The following studies added up the empirical evidence which highlighted that the students having positive views contributed more to online learning amid the COVID-19 pandemic.

Furthermore, the results show the effect on the students who failed which can be seen in their perception and the satisfaction of their course and the findings are contrary to those who were having past studies (Bernard et al., 2004; Morris, 2010). It can be possible that students gave the general point-of-view regarding the online learner perception rather than giving the specific point-of-view in the pandemic situation.

However, it can be concluded that all the learners who have the positive insight regarding the online learning which includes the comfort zone, accessibility, interactivity and adaptability, knowledge, acquisition, and the ease of learning are those who intended not to give their input in one activity but to give input in every course for the sake of progression even in the crisis of COVID-19.

Future studies should investigate the effects of COVID-19 on online learning that further exerted in any observable view. Parents' involvement is important in signifying concern in their children's studies. The findings of the current study have been viewed differently when compared to past studies. The authors highlighted that the internet is not a good indicator to predict or analyse that students' performance in learning platforms because they are not physically present as the pandemic situation has forced for online learning. They are doing work through technology platform that might be different from one learner to another (Bernard et al., 2004; Hung, 2012). The online discussion was an analysis where every learner is required to post discussion regarding the week's activity and discuss the issues asked by the instructor, lecture, or peers. Therefore, learners who are using computers might respond positively but they are well informed regarding the messages that were posted and the interaction done there with instructors and peers.

In addition to the above explanation, technology is the platform where students are motivated in learning which directly influence the online discussing score. This is possible that teachers can easily conduct the course online and teach them in detail by the 
softwares used in meetings. The instructors were not the ones who post the work after the lecture but it is also the students who are required to post the work that was given by the instructor in the discussion box. The instructors are then required to evaluate every input where the ideas will be shared online to encourage student participation, hence it can be proved that online discussion platform is effective. The COVID-19 crisis challenged the education systems around the world and could bring out the best version of online education as it has forced the schools and universities around the world to shift the paradigm towards online learning.

The following study has an objective to study the usefulness of online learning for improving the quality of instruction, the quality of environment, the quality of teacher, and the quality of family cooperation during the COVID-19 pandemic in Indonesia. Along with this, the contribution of the study highlighted the implication platform as an online course instructor along with educational system developers. For example, in the first week when the online class started, the format was discussed along with the assignment and the requirement. The instructor helped the students by making the online learning environment more positive by promoting the features of the online learning platform and by focusing on the student's ability. Instructors were required to invite the students who are being enrolled in the course which will significantly help during the pandemic.
Along with the above statement, it becomes an important activity to continue the study in which students were required not only to respond to the questions of the instructor but also to give feedback regarding the online class. . The management took new steps to increase the effectiveness in this area of the pandemic situation. With proper guidelines, students were required to perform better in discussions, activities and tasks. Lastly, instructors must help every individual to keep them motivated as they are not physically present in the online learning platform in the COVID-19 situation.

As every research has its limitations, there are future recommendations for those researchers who will work on the same platform. Firstly, they are encouraged to find a study which are not generalised to a specific and clear extent because as the study has been conducted in small groups like targeting the undergraduate students and the survey response is not easy to get. Secondly, the study must have a structural model that helps to understand the relationship between the result that were received by the exams and the performance in online class along with the course satisfaction and the course environment. In the future, the study must be done with proper variables. Furthermore, the data collected from the selfreported questionnaires must be retrieved from sources that provide the direct study, good information, and less quantity of error. In the future, survey researchers can interview on the feedback and th must be done on other area as well to get the generalised results.

\section{References:}

Akyüz, G. (2014). The effects of student and school factors on mathematics achievement in timss 2011.

Al-Samarraie, H., Teng, B. K., Alzahrani, A. I., \&Alalwan, N. (2018). E-learning continuance satisfaction in higher education: A unified perspective from instructors and students. Studies in Higher Education, 43(11), 2003-2019.

Alzahrani, M. G., \& O'Toole, J. M. (2017). The impact of internet experience and attitude on student preference for blended learning. Journal of Curriculum and Teaching, 6(1), 65-78. 
Barnard, L., Lan, W. Y., To, Y. M., Paton, V. O., \& Lai, S.-L. (2009). Measuring self-regulation in online and blended learning environments. The Internet and Higher Education, 12(1), 1-6.

Bates, A. T. (2018). Teaching in a digital age: Guidelines for designing teaching and learning.

Bates, B. (2019). Learning theories simplified:... And how to apply them to teaching. SAGE Publications Limited.

Bernard, R. M., Brauer, A., Abrami, P. C., \&Surkes, M. (2004). The development of a questionnaire for predicting online learning achievement. Distance Education, 25(1), 31-47.

Bolliger, D. U., \&Halupa, C. (2018). Online student perceptions of engagement, transactional distance, and outcomes. Distance Education, 39(3), 299-316.

Brian, K. (2007). Oecd insights human capital how what you know shapes your life: How what you know shapes your life. OECD publishing.

Broadbent, J., \& Poon, W. L. (2015). Self-regulated learning strategies \& academic achievement in online higher education learning environments: A systematic review. The Internet and Higher Education, 27, 1-13.

Buaraphan, K. (2012). Educational supervisors' metaphorical roots of beliefs about teaching and learning. Educational Research and Reviews, 7(12), 282.

Cheng, Y. C., \& Cheung, W. M. (2004). Four types of school environment: Multilevel selfmanagement and educational quality. Educational Research and Evaluation, 10(1), 71-100.

Chow, W. S., \& Shi, S. (2014). Investigating students' satisfaction and continuance intention toward e-learning: An extension of the expectation-confirmation model. Procedia-Social and Behavioral Sciences, 141, 1145-1149.

Cigdem, H., \& Yildirim, O. G. (2014). Predictors of c\# programming language self efficacy among vocational college students. International Journal on New Trends in Education and Their Implications, 5(3), 145-153.

Cochran, W. G. (2007). Sampling techniques. John Wiley \& Sons.

Crawford, J., Butler-Henderson, K., Rudolph, J., \& Glowatz, M. (2020). Covid-19: 20 countries' higher education intra-period digital pedagogy responses. Journal of Applied Teaching and Learning (JALT), 3(1).

De Paepe, L., Zhu, C., \&Depryck, K. (2018). Learner characteristics, learner achievement and time investment in online courses for dutch 12 in adult education. Turkish Online Journal of Educational Technology-TOJET, 17(1), 101-112.

Deci, E. L., \& Ryan, R. M. (1985). Self-determination and intrinsic motivation in human behavior.

Dray, B. J., Lowenthal, P. R., Miszkiewicz, M. J., Ruiz-Primo, M. A., \&Marczynski, K. (2011). Developing an instrument to assess student readiness for online learning: A validation study. Distance Education, 32(1), 29-47.

Duggan, A., Hess, B., Morgan, D., Kim, S., \& Wilson, K. (2001). Measuring students' attitudes toward educational use of the internet. Journal of Educational Computing Research, 25(3), 267-281.

Dziuban, C., Moskal, P., Thompson, J., Kramer, L., DeCantis, G., \&Hermsdorfer, A. (2015). Student satisfaction with online learning: Is it a psychological contract? Online Learning, 19(2), n2. 
Erberber, E. (2010). Analyzing turkey's data from timss 2007 to investigate regional disparities in eighth grade science achievement. The impact of international achievement studies on national education policymaking (international perspectives on education and society, Volume 13), Emerald Group Publishing Limited, pp. 119-142.

Fisher, D., \&Cresswell, J. (1998). Actual and ideal principal interpersonal behaviour. Learning Environments Research, 1(2), 231-247.

Fornell, C., \& Larcker, D. F. (1981). Structural equation models with unobservable variables and measurement error: Algebra and statistics. Journal of marketing research, 18(3), 382-388.

Gamage, D. T. (2001). British reforms in school management: A decade of experience with lms. Studies in International Relations, 22(2), 23-54.

Glasser, W. (1999). Okuldakalitelieğitim. İstanbul: BeyazYayınları, (Çev: Ulaş Kaplan).

Goddard, R., \& Villanova, P. (2006). Designing surveys and questionnaires for research. The psychology research handbook: A guide for graduate students and research assistants, 114125.

Gomm, R. (2008). Social research methodology: A critical introduction. Macmillan International Higher Education.

Hair, J. F., Black, W. C., Babin, B. J., \& Anderson, R. E. (2010). Multivariate data analysis a global perspective (Vol. 7). New Jersey: Pearson Education.

Hair, J. F., Ringle, C. M., \&Sarstedt, M. (2011). Pls-sem: Indeed a silver bullet. Journal of Marketing theory and Practice, 19(2), 139-152.

Hao, Y. (2016). Middle school students' flipped learning readiness in foreign language classrooms: Exploring its relationship with personal characteristics and individual circumstances. Computers in Human Behavior, 59, 295-303.

Henseler, J., Dijkstra, T. K., Sarstedt, M., Ringle, C. M., Diamantopoulos, A., Straub, D. W., . . . Calantone, R. J. (2014). Common beliefs and reality about pls: Comments on rönkkö and evermann (2013). Organizational Research Methods, 17(2), 182-209.

Horzum, M. B., Kaymak, Z. D., \& Gungoren, O. C. (2015). Structural equation modeling towards online learning readiness, academic motivations, and perceived learning. Educational Sciences: Theory \& Practice, 15(3).

Hung, M.-L. (2012). A study of the relationship between college-level online learners' readiness and learning performance. [Unpublished doctoral dissertation]. National Chiao Tung University.

Hung, M.-L. (2016). Teacher readiness for online learning: Scale development and teacher perceptions. Computers \& Education, 94, 120-133.

Hung, M.-L., Chou, C., Chen, C.-H., \& Own, Z.-Y. (2010). Learner readiness for online learning: Scale development and student perceptions. Computers \& Education, 55(3), 1080-1090.

Hyde, K. F. (2000). Recognising deductive processes in qualitative research. Qualitative market research: An international journal.

Joyce, M., \& Kirakowski, J. (2015). Measuring attitudes towards the internet: The general internet attitude scale. International Journal of Human-Computer Interaction, 31(8), 506-517.

Kajornboon, A. B. (2005). Using interviews as research instruments. E-journal for Research Teachers, 2(1), 1-9. 
Ke, F., \& Kwak, D. (2013). Online learning across ethnicity and age: A study on learning interaction participation, perception, and learning satisfaction. Computers \& Education, 61, 43-51.

Keramati, A., Afshari-Mofrad, M., \&Kamrani, A. (2011). The role of readiness factors in elearning outcomes: An empirical study. Computers \& Education, 57(3), 1919-1929.

Krejcie, R. V., \& Morgan, D. W. (1970). Determining sample size for research activities. Educational and psychological measurement, 30(3), 607-610.

Kuo, Y.-C. (2014). Accelerated online learning: Perceptions of interaction and learning outcomes among africanamerican students. American Journal of Distance Education, 28(4), 241-252.

Kuo, Y.-C., Walker, A. E., Belland, B. R., \& Schroder, K. E. (2013). A predictive study of student satisfaction in online education programs. The International Review of Research in Open and Distributed Learning, 14(1), 16-39.

Lee, S. J., Srinivasan, S., Trail, T., Lewis, D., \& Lopez, S. (2011). Examining the relationship among student perception of support, course satisfaction, and learning outcomes in online learning. The Internet and Higher Education, 14(3), 158-163.

Lezotte, L. (1991). Correlates of effective schools; the first and second generation. Effective schools products. In: LTD, Okemos, ML.

Liaw, S.-S., \& Huang, H.-M. (2013). Perceived satisfaction, perceived usefulness and interactive learning environments as predictors to self-regulation in e-learning environments. Computers \& Education, 60(1), 14-24.

Liaw, S.-S., Huang, H.-M., \& Chen, G.-D. (2007). Surveying instructor and learner attitudes toward e-learning. Computers \& Education, 49(4), 1066-1080.

Lu, J., Yu, C.-S., \& Liu, C. (2003). Learning style, learning patterns, and learning performance in a webct-based mis course. Information \& Management, 40(6), 497-507.

Marczyk, G., DeMatteo, D., \& Festinger, D. (2005). Essentials of research design and methodology. John Wiley \& Sons Inc.

McFarland, D., \& Hamilton, D. (2005). Factors affecting student performance and satisfaction: Online versus traditional course delivery. Journal of Computer Information Systems, 46(2), 25-32.

McVay, M. (2000). How to be a successful distance learning student: Learning on the internet. Pearson Custom Pub.

Morris, T. A. (2010). Exploring community college student perceptions of online learning. Northcentral University.

Mullis, I. V., Martin, M. O., Foy, P., \& Arora, A. (2012). Timss 2011 international results in mathematics. TIMSS \& PIRLS International Study Center Chestnut Hill, MA.

Newman, D., Deyoe, M., Connor, K., \&Lamendola, J. (2014). Promoting active learning through the flipped classroom model, 113-131.

Nitzl, C. (2018). Management accounting and partial least squares-structural equation modelling (pls-sem): Some illustrative examples. In Partial least squares structural equation modeling (pp. 211-229). Springer.

OECD. (2013). The oecd guidelines for multinational enterprises. Retrieved from Education at a Glance: http://mneguidelines.oecd.org/MNE-Annual-Report-2013-Summary.pdf 
Paechter, M., Maier, B., \& Macher, D. (2010). Students' expectations of, and experiences in elearning: Their relation to learning achievements and course satisfaction. Computers \& Education, 54(1), 222-229.

Picciano, A. G. (2002). Beyond student perceptions: Issues of interaction, presence, and performance in an online course. Journal of Asynchronous learning networks, 6(1), 21-40.

Pragholapati, A. (2020). Covid-19 impact on students.

Richardson, A. G., \& Thomas, A. A. (1989). Characteristics of the effective teacher as perceived by pupils and teachers. A caribbean case study.

Roy, S., Bhattacharya, S., \& Das, P. (2020). Identification of e-learning quality parameters in Indian context to make it more effective and acceptable. Proceedings on Engineering Sciences, 2(3), 209-222.

Sahin, I., \& Shelley, M. (2008). Considering students' perceptions: The distance education student satisfaction model. Journal of Educational Technology \& Society, 11(3), 216-223.

Sarstedt, M., Ringle, C. M., Smith, D., Reams, R., \& Hair, J. F. (2014). Partial least squares structural equation modeling (pls-sem): A useful tool for family business researchers. Journal of Family Business Strategy, 5(1), 105-115.

Scott, G., \& Garner, R. (2013). Doing qualitative research: Designs, methods, and techniques. Pearson Upper Saddle River.

Setiati, S., \& Azwar, M. K. (2020). Covid-19 and indonesia. Acta Medica Indonesiana, 52(1), 84-89.

Setiawan, A. R. (2020). Scientific literacy worksheets for distance learning in the topic of coronavirus 2019 (covid-19).

Sezer, R., Güner, N., \& Ispir, O. (2012). Teachers' perspective on whether the mathematics reform will change turkey's ranking in timss. Education, 133(2), 391-411.

Shelton, B. E., Hung, J.-L., \& Lowenthal, P. R. (2017). Predicting student success by modeling student interaction in asynchronous online courses. Distance Education, 38(1), 59-69.

Smith, P. J., Murphy, K. L., \& Mahoney, S. E. (2003). Towards identifying factors underlying readiness for online learning: An exploratory study. Distance Education, 24(1), 57-67.

Stokes, S. P. (2003). Temperament, learning styles, and demographic predictors of college student satisfaction in a digital learning environment.

Sun, P.-C., Tsai, R. J., Finger, G., Chen, Y.-Y., \& Yeh, D. (2008). What drives a successful elearning? An empirical investigation of the critical factors influencing learner satisfaction. Computers \& Education, 50(4), 1183-1202.

Sun, Z., Xie, K., \& Anderman, L. H. (2018). The role of self-regulated learning in students' success in flipped undergraduate math courses. The Internet and Higher Education, 36, 4153.

Ting, D. S. W., Carin, L., Dzau, V., \& Wong, T. Y. (2020). Digital technology and covid-19. Nature medicine, 26(4), 459-461.

Townsend, T. (1997). What makes schools effective? A comparison between school communities in australia and the USA. School Effectiveness and School Improvement, 8(3), 311-326.

Ubuz, B., \& Sarı, S. (2009). Primary teachers' candidates' views on good teacher. Ondokuz Mayls University Journal of Education, 28, 53-61. 
Viner, R. M., Russell, S. J., Croker, H., Packer, J., Ward, J., Stansfield, C., . . Booy, R. (2020). School closure and management practices during coronavirus outbreaks including covid-19: A rapid systematic review. The Lancet Child \& Adolescent Health.

Walker, P., Whittaker, C., Watson, O., Baguelin, M., Ainslie, K., Bhatia, S., . . . Cattarino, L. (2020). Report 12: The global impact of covid-19 and strategies for mitigation and suppression.

Warner, D., Christie, G., \& Choy, S. (1998). Readiness of vet clients for flexible delivery including on-line learning. Brisbane: Australian National Training Authority.

Wei, H.-C., \& Chou, C. (2019). Relationships among college learners' online learning perceptions, behaviors, and achievements via the self-determination theory approach. Paper presentation. Retrieved from https://www.tandfonline.com/action/showCitFormats? doi $=10.1080 \% 2 \mathrm{~F} 01587919.2020 .1724768$

Wei, H.-C., Peng, H., \& Chou, C. (2015). Can more interactivity improve learning achievement in an online course? Effects of college students' perception and actual use of a coursemanagement system on their learning achievement. Computers \& Education, 83, 10-21.

Weidlich, J., \& Bastiaens, T. J. (2018). Technology matters-the impact of transactional distance on satisfaction in online distance learning. International Review of Research in Open and Distributed Learning, 19(3).

WHO. (2020). Coronavirus disease 2019, covid-19. COVID-19 Retrieved from https://www.who.int/emergencies/diseases/novel-coronavirus-2019

Worldometer. (2020). Coronavirus case records.

Wößmann, L. (2003). Schooling resources, educational institutions and student performance: The international evidence. Oxford bulletin of economics and statistics, 65(2), 117-170.

Yang, D., Baldwin, S., \&Snelson, C. (2017). Persistence factors revealed: Students' reflections on completing a fully online program. Distance Education, 38(1), 23-36.

Yu, T., \& Richardson, J. C. (2015). An exploratory factor analysis and reliability analysis of the student online learning readiness (solr) instrument. Online Learning, 19(5), 120-141.

Fahrurrozi

Universitas Negeri Jakarta, Jakarta,

Indonesia

fahrurrozi@unj.ac.id

\section{Iva Sarifah}

Universitas Negeri Jakarta,

Jakarta,

Indonesia

ivasarifah@unj.ac.id

\section{Murtono}

Universitas Muria Kudus, Jawa Tengah,

Indonesia

murtono@umk.ac.id

\section{Ratna Sari Dewi}

Universitas Islam Negeri

Syarif Hidayatullah Jakarta,

Jakarta,

Indonesia

ratna@uinjkt.ac.id

\section{Ika Lestari}

Universitas Negeri Jakarta,

Jakarta,

Indonesia

ikalestari@unj.ac.id 


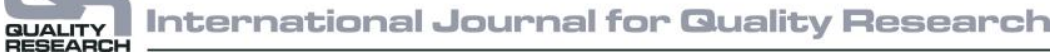

